\title{
Hemorrhagic fever with renal syndrome with secondary hemophagocytic lymphohistiocytosis in West China: a case report
}

\author{
Xiaoling Yang, Chuan Wang, Libo Wu, Xiaoqian Jiang, Sumei Zhang and Fuchun Jing*
}

\begin{abstract}
Background: Hemophagocytic lymphohistiocytosis $(\mathrm{HLH})$ is a life-threatening disease characterized by an excessive systemic inflammatory response, which can be classified as primary HLH (pHLH) and secondary HLH (sHLH). Viruses are the primary pathogens causing sHLH. Hemorrhagic fever with renal syndrome (HFRS) is a rodent-borne disease caused by hantaviruses. Its main characteristics include fever, circulatory collapse with hypotension, hemorrhage, and acute kidney injury. The case of HFRS presented with sHLH is very rare in clinic. We reported the HFRS inducing by Hantaan virus (HTNV) presented with SHLH as the first case in Shaanxi province of west China.
\end{abstract}

Case presentation: A case of HFRS in 69-year-old Chinese woman, which had persistent fever, cytopenia, coagulopathy, ferritin significantly increased, hepatosplenomegaly and superficial lymphadenopathy. The hemophagocytosis was found in bone marrow, which was consistent with the characteristics of the HLH. The patient recovered completely after timely comprehensive treatments.

Conclusions: HTNV should be considered as one of the underlying viruses resulting in hemophagocytosis, and if occurs, the early diagnosis and rapid therapeutic intervention are very important to the prognosis of sHLH.

Keywords: Hemorrhagic fever with renal syndrome, Hantaan virus, Secondary hemophagocytic lymphohistiocytosis, Prognosis

\section{Background}

Hemophagocytic lymphohistiocytosis (HLH) is a reactive, hyperplastic disease of mononuclear phagocyte system, which is characterized by an excessive systemic inflammatory response. HLH can be classified as primary and secondary ones. The primary HLH (pHLH) is relatively rare and often occurs in infants aged $0-2$ years, accompanied by genetic mutations and poor prognosis. The secondary HLH (sHLH), oppositely, is usually induced by a variety of medical conditions, including infections, autoimmune diseases, malignancies, immunodeficiencies and hematopoietic stem cell or organ transplantations, often associated with a better prognosis if recognized early [1]. Viruses, such as Epstein-Barr virus (EBV), adenovirus and herpes

\footnotetext{
* Correspondence: fleming7798@163.com

Department of Infectious Diseases, Baoji People's Hospital Affiliated to Yan'an University, Baoji 721000, Shaanxi province, China
}

virus, are the primary pathogens causing sHLH. Occasionally, the bacterial, fungal, or parasitic infections may also cause it [2]. In most cases, sHLH patients could be treated successfully if the diagnosis and therapeutic intervention are timely [3].

Hemorrhagic fever with renal syndrome (HFRS) is a rodent-borne disease caused by hantaviruses, which is primarily characterized by fever, circulatory collapse with hypotension, hemorrhage and acute kidney injury [4]. HFRS mainly distributes in Asian and European countries [5]. In Europe, the most important serotype of hantaviruses is Puumala virus (PUUV) [6] but in Asia, Hantaan virus (HTNV) and Seoul virus (SEOV) are the common ones [7]. Though in China there is another serotype, Dobrava-Belgrade virus (DOBV), HTNV is still the commonest pathogen resulting in HFRS in Shaanxi province of west China [8].

(c) The Author(s). 2019 Open Access This article is distributed under the terms of the Creative Commons Attribution 4.0 International License (http://creativecommons.org/licenses/by/4.0/), which permits unrestricted use, distribution, and reproduction in any medium, provided you give appropriate credit to the original author(s) and the source, provide a link to the Creative Commons license, and indicate if changes were made. The Creative Commons Public Domain Dedication waiver (http://creativecommons.org/publicdomain/zero/1.0/) applies to the data made available in this article, unless otherwise stated. 
The case of HFRS presented with SHLH is very rare in clinic. In the past decades, only two cases have been reported in France and South Korea respectively [9, 10]. There is no such a case reported in China, especially in west Shaanxi province. We provided the first case of HFRS with sHLH in this region.

\section{Case presentation}

A 69-year-old Chinese woman was admitted to our hospital with fever and myalgia persisting for 2 days on $\mathrm{Au}-$ gust 12, 2017. The patient was not treated at a local clinic. Except a history of hypertension for 3 years, she had no other specific diseases or familial medical history. She lived in a rural area from her birth and often worked in fields. The vital signs were body temperature $39.0^{\circ} \mathrm{C}$, heart rate $122 / \mathrm{min}$, respiratory rate $23 / \mathrm{min}$ and blood pressure $130 / 80 \mathrm{mmHg}$. The positive physical examination included a poor general condition, petechiae in the chest, palpable lymph nodes in the neck and axilla, and rough breathing sounds in lungs. Upon admission, hematologic tests revealed that her leukocyte count was $1.1 \times 10^{9} / \mathrm{L}$, erythrocyte count $2.88 \times 10^{12} / \mathrm{L}$, hemoglobin $102 \mathrm{~g} / \mathrm{L}$, platelet count $36.0 \times 10^{9} / \mathrm{L}$, and abnormal lymphocytes $3 \%$. Blood biochemistry showed blood urea nitrogen 14.17 $\mathrm{mmol} / \mathrm{L}$, creatinine $135.1 \mu \mathrm{mol} / \mathrm{L}$, lactic dehydrogenase 989.4 IU/L, ferritin $>2000 \mu \mathrm{g} / \mathrm{L}$ and procalcitonin 66.29 $\mathrm{ng} / \mathrm{ml}$. The prothrombin time was $18.7 \mathrm{~s}$, partial thromboplastin time $86.3 \mathrm{~s}$, fibrinogen $1.90 \mathrm{~g} / \mathrm{L}$ and D-Dimer over $20 \mu \mathrm{g} / \mathrm{ml}$. Enzyme-linked immunosorbent assays of IgM and IgG antibodies for HFRS were both positive and the serotype of hantaviruses was HTNV. Additional serologic tests showed that antibodies against EBV, cytomegalovirus, herpes, adenovirus, respiratory syncytial virus, influenza virus $A$ and $B$, human immunodeficiency virus, Hepatitis A, B, and C viruses, Legionella pneumophila, mycoplasma pneumoniae, chlamydia pneumoniae and rickettsia were negative. The scan of chest and abdomen by computed tomography demonstrated that hypostatic pneumonia and hepatosplenomegaly. The ultrasound examination to superficial lymph nodes revealed that multiple lymphadenectasis in the neck, axilla and groin. After 4-day hyperthermia (a peak temperature of up to $42{ }^{\circ} \mathrm{C}$ ) from admission, the patient's condition deteriorated gradually. Blood test showed that leukocyte count was $2.6 \times 10^{9} / \mathrm{L}$, erythrocyte count $1.91 \times 10^{12} / \mathrm{L}$, hemoglobin $70 \mathrm{~g} / \mathrm{L}$, platelet count $10.0 \times 10^{9} / \mathrm{L}$, abnormal lymphocytes $18 \%$, blood urea nitrogen $13.64 \mathrm{mmol} / \mathrm{L}$, creatinine $200.6 \mu \mathrm{mol} / \mathrm{L}$, lactic dehydrogenase $1169.0 \mathrm{IU} / \mathrm{L}$, alanine aminotransferase 63.4 U/L, aspartate aminotransferase $260.7 \mathrm{U} / \mathrm{L}$, albumin $28.3 \mathrm{~g} / \mathrm{L}$, creatine kinase $1859.4 \mathrm{U} / \mathrm{L}$, creatine kinase$\mathrm{MB}$ 58.3 IU/L, hydroxybutyrate dehydrogenase 816.0 IU/L, HDL-cholesterol $0.51 \mathrm{mmol} / \mathrm{L}$, LDL-cholesterol $0.38 \mathrm{mmol} / \mathrm{L}$, total cholesterol $1.34 \mathrm{mmol} / \mathrm{L}$, triglyceride $1.04 \mathrm{mmol} / \mathrm{L}$, the prothrombin time $18.5 \mathrm{~s}$, partial thromboplastin time $100.2 \mathrm{~s}$ and fibrinogen $1.34 \mathrm{~g} / \mathrm{L}$. For clear comparison and understanding, the results of these blood parameters with their normal range on admission day 1 and day 4 were listed in Table 1 . The immature cells and nucleated erythrocytes were found by peripheral blood smears. The concurrently cultures of blood, urine and sputum did not reveal any pathogen. The formation of histiocytes with prominent hemophagocytosis was discovered through bone marrow aspiration (Fig. 1).

In the treatment of the patient, we just focused on the original disease HFRS, mainly taking the measurements of antiviral agent ribavirin, diuretic and intermittent hemodialysis in the initial and oliguric stages, antibacterial drug cefoperazone sodium and sulbactam sodium in dealing with pulmonary infection, maintenance of water and electrolyte acid-base balance and other supportive therapies when needed. No corticosteroids and specific therapy were applied. The patient recovered completely after the above comprehensive treatments on day 26. Bone marrow aspiration was performed again on September 7 and the result only showed secondary anemia but no signs of hemophagocytosis. The 3 months follow-up blood tests after her discharge from our hospital demonstrated normal outcomes.

\section{Discussion and conclusions}

HFRS is mainly caused by four kinds of viruses, HTNV, PUUV, SEOV and DOBV, each of which may result in a severe outcome as its high mortality. The common

Table 1 Laboratory tests of the patient on admission day 1 and day 4

\begin{tabular}{llll}
\hline Laboratory tests & Day 1 & Day 4 & Normal range \\
\hline leukocyte count $\left(\times 10^{9} / \mathrm{L}\right)$ & 1.1 & 2.6 & $3.5-9.5$ \\
erythrocyte count $\left(\times 10^{12} / \mathrm{L}\right)$ & 2.88 & 1.91 & $3.8-5.1$ \\
hemoglobin $(\mathrm{g} / \mathrm{L})$ & 102 & 70 & $115-150$ \\
platelet count $\left(\times 10^{9} / \mathrm{L}\right)$ & 36 & 10 & $125-354$ \\
abnormal lymphocytes $(\%)$ & 3 & 18 & $0-2$ \\
ALT $(\mathrm{U} / \mathrm{L})$ & - & 63.4 & $7-45$ \\
AST $(\mathrm{U} / \mathrm{L})$ & 202 & 260.7 & $13-40$ \\
$\mathrm{LDH}(\mathrm{U} / \mathrm{L})$ & 989.4 & 1169 & $109-245$ \\
BUN $(\mathrm{mmol} / \mathrm{L})$ & 14.17 & 13.64 & $2.86-8.2$ \\
Creatinine $(\mu \mathrm{mol} / \mathrm{L})$ & 135.1 & 200.6 & $40-90$ \\
PT $($ seconds) & 18.7 & 18.5 & $10.5-14.5$ \\
APTT $($ seconds $)$ & 86.2 & 100.2 & $25-45$ \\
Fibrinogen $(\mathrm{g} / \mathrm{L})$ & 1.9 & 1.34 & $2-4$ \\
Ferritin $(\mu \mathrm{g} / \mathrm{L})$ & $>2000$ & - & $15-650$ \\
Triglyceride $(\mathrm{mmol} / \mathrm{L})$ & - & 1.04 & $0-2.3$ \\
\hline ALT & &
\end{tabular}

$A L T$ alanine aminotransferase, $A S T$ aspartate aminotransferase, $B U N$ blood urea nitrogen, $L D H$ lactic dehydrogenase, $P T$ prothrombin time, $A P T T$ partial thromboplastin time 


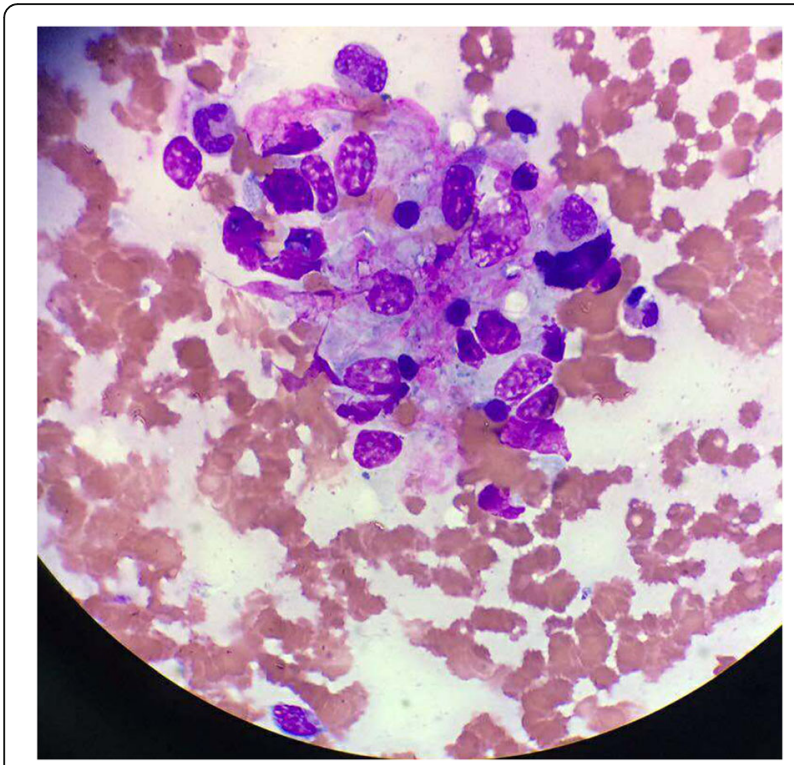

Fig. 1 Bone marrow aspirate showing phagocytosis of neutrophil, nucleated erythrocyte, and platelets by benign histiocytes (Wright's stain, $\times 100)$

clinical features of HFRS include fever, hypotension or shock, hemorrhage and acute kidney injury [4]. Though there were many researches probed the pathogenesis of this globally widespread disease in the past decades, there is still not a satisfied answer found to date [11]. Some believed that the infection of HTNV could induce human vascular endothelial injury and increase vascular permeability, which formed the pathological basis of HFRS and led to plasma exosmosis [12, 13]. Some thought that the viral infection could trigger the immune response such as $T$ cell reaction, $B$ cell reaction and cytokine storm, which may damage the vascular endothelium and induce plasmocyte into immature leucocyte [14-16]. This can partly explain the increase of the amount of immature leucocyte in the early stage of HFRS. Whatever the pathogenesis is, our report provided such a case with clear diagnosis of severe HFRS according to the detection of the antibody of HTNV and the clinical features and other laboratory or imaging tests.

HLH is a life-threatening disease characterized by an excessive systemic inflammatory response. Its prognosis is generally poor and the fatality rate could be as high as $50 \%$ [1]. The primary presentations of HLH in clinic are unexplained fever, hepatosplenomegaly, lymphadenopathy, cytopenia and coagulopathy. Hemophagocytosis in the bone marrow, spleen and lymph nodes is also an important diagnostic clue. In our case, the patient had persistent fever, hepatosplenomegaly, cytopenia, hypofibrinogenemia, increased blood levels of ferritin and hemophagocytosis in the bone marrow, which were completely consistent with the diagnostic criteria of HLH listed in Table 2 [17]. Besides, the patient had elevated blood lactate dehydrogenase, coagulopathy, abnormal liver function and superficial lymphadenopathy.

The treatment of HLH is difficult, especially when it is secondary to another life-threatening disease such as HFRS. Timely diagnosis and treatment of the primary disease are vital to the prognosis of SHLH [18]. The use of antiviral agents, corticosteroids, immunoglobulin and even immune inhibitors such as etoposide and cyclosporine $\mathrm{A}$ is routine measurements in controlling the deterioration of the disease, especially in the treatment of EBV associated HLH [17]. Because the EBV related HLH is usually difficult to cure and fatal as its serious complications, e.g. hemorrhage, infection, or multiorgan failure [19]. However, in our case the patient was only cured with the administration of anti-infective agents, diuresis, hemodialysis and supportive therapies, no corticosteroids using in the treatment, indicating that the early diagnosis and comprehensive treatments to the primary infection is crucial to the prognosis of HLH secondary to HFRS. As sHLH is more often secondary to a variety of pathogen infections, including viruses, bacteria, fungi and parasites, rarely secondary to a same pathogen with a great amount, the further study of the pathogenesis of sHLH is usually very difficult in reality. So far, there were only two cases of sHLH after HFRS reported. Therefore, we can hardly know how the pathogenesis alters due to the activation of HLH by the HTNV.

In conclusion, we reported the first case of HFRS with sHLH caused by HTNV in China. That means HTNV should be considered as one of the underlying viruses resulting in hemophagocytosis, and if occurs, the early diagnosis and timely therapeutic intervention are very important to its prognosis.

Table 2 Diagnostic Criteria of Hemophagocytic Lymphohistiocytosis (HLH) [17]

Molecular diagnosis of $\mathrm{HLH}$ or the presence of at least 5 of 8 criteria:

1. Fever

2. Splenomegaly

3. Cytopenia (affecting at least 2 lineages in the peripheral blood), Hemoglobin levels $<90 \mathrm{~g} / \mathrm{L}$ (in infants $<4$ weeks old, hemoglobin $<100 \mathrm{~g} / \mathrm{L})$, Platelets $<100 \times 10^{9} / \mathrm{L}$, Neutrophils $<1.0 \times 10^{9} / \mathrm{L}$

4. Hypertriglyceridemia and/or hypofibrinogenemia: Fasting triglycerides $\geq 3.0 \mathrm{mmol} / \mathrm{L}$ (ie, $\geq 265 \mathrm{mg} / \mathrm{dl}$ ), Fibrinogen $\leq 1.5 \mathrm{~g} / \mathrm{L}$

5. Documented hemophagocytosis in the bone marrow, spleen, or lymph nodes

6. Low or absent natural killer cell activity

7. Ferritin $\geq 500 \mu \mathrm{g} / \mathrm{L}$

8. Soluble CD25 (ie, soluble interleukin-2 receptor) $\geq 2400 \mathrm{U} / \mathrm{ml}$ 


\section{Abbreviations}

DOBV: Dobrava-Belgrade virus; EBV: Epstein-Barr virus; HFRS: Hemorrhagic fever with renal syndrome; HLH: Hemophagocytic lymphohistiocytosis; HTNV: Hantaan virus; pHLH: primary Hemophagocytic lymphohistiocytosis; PUUV: Puumala virus; SEOV: Seoul virus; sHLH: secondary Hemophagocytic lymphohistiocytosis

\section{Acknowledgements}

The authors are grateful to professor Haiying Li and technician Yajuan Wang for their technical assistances.

\section{Authors' contributions}

YXL and JFC drafted the manuscript. YXL, WC, WLB, JXQ and ZSM collected the data. JFC finalized the manuscript. All authors approved the final version of the manuscript.

\section{Funding}

No funding was obtained for this case report.

\section{Availability of data and materials}

No applicable. All major data generated or analyzed during this study were included in this article.

\section{Ethics approval and consent to participate}

The report was approved by the Ethical and Clinical Research Committee of Baoji People's Hospital Affiliated to Yan'an University.

\section{Consent for publication}

Written informed consent was obtained from the patient for publication of this case report and any accompanying images.

\section{Competing interests}

The authors declare that they have no competing interests.

Received: 13 February 2019 Accepted: 22 May 2019

Published online: 04 June 2019

\section{References}

1. Janka GE, Lehmberg K. Hemophagocytic syndromes-an update. Blood Rev. 2014:28:135-42

2. Filipovich $\mathrm{AH}$, Chandrakasan S. Pathogenesis of hemophagocytic lymphohistiocytosis. Hematol Oncol Clin North Am. 2015;29:895-902.

3. Imashuku S. Advances in the management of hemophagocytic lymphohistiocytosis. Int J Hematol. 2000;72(1):1-11.

4. Lee HW, van der Groen G. Hemorrhagic fever with renal syndrome. Prog Med Virol. 1989:36:62-102.

5. Bi Z, Formenty PB, Roth CE. Hantavirus infection: a review and global update. J Infect Dev Ctries. 2008;2(1):3-23.

6. Amirpour Haredasht S, Barrios M, Farifteh J, Maes P, Clement J, Verstraeten WW, et al. Ecological niche modelling of bank voles in Western Europe. Int $J$ Environ Res Public Health. 2013:10(2):499-514.

7. Zhang WY, Fang LQ, Jiang JF, Hui FM, Glass GE, Yan L, et al. Predicting the risk of hantavirus infection in Beijing, People's Republic of China. Am J Trop Med Hyg. 2009;80(4):678-83.

8. Jonsson CB, Figueiredo LT, Vapalahti O. A global perspective on hantavirus ecology, epidemiology, and disease. Clin Microbiol Rev. 2010;23:412-41.

9. Baty $\mathrm{V}$, Schuhmacher $\mathrm{H}$, Bourgoin $\mathrm{C}$, Latger $\mathrm{V}$, Buisine J, May $\mathrm{T}$, et al. Hemophagocytic syndrome and hemorrhagic fever with renal syndrome. Presse Med. 1998:27:1577.

10. Lee J-J, Chung $1-J$, Shin D-H, et al. Hemorrhagic fever with renal syndrome presenting with Hemophagocytic Lymphohistiocytosis. Emerg Infect Dis. 2002:8(2):209-10.

11. Jiang $H$, Du H, Wang LM, Wang PZ, Bai XF. Hemorrhagic fever with renal syndrome: pathogenesis and clinical picture. Front Cell Infect Microbiol. 2016;6:178.

12. Gavrilovskaya IN, Gorbunova EE, Mackow NA, Mackow ER. Hantaviruse direct endothelial cell permeability by sensitizing cells to the vascular permeability factor VEGF, while angiopoietin 1 and sphingosine 1 phosphateinhibithantavirus-directedpermeability. J.Virol. 2008;82:5797-806.
13. Gorbunova EE, Gavrilovskaya IN, Pepini T, Mackow ER. VEGFR2 and Src kinase inhibitors suppress Andes virus-induced endothelial cell permeability. J Virol. 2011:85:2296-303.

14. Easterbrook JD, Zink MC, Klein SL. Regulatory T cells enhance persistence of the zoonotic pathogen Seoul virus in its reservoir host. Proc Natl Acad Sci U S A. 2007;104:15502-7.

15. Khaiboullina SF, Morzunov SP. St. Jeor, S. C. hantavirus: molecular biology, evolution and pathogenesis. Curr Mol Med. 2005a;5:773-90.

16. Vaheri A, Strandin T, Hepojoki J, Sironen T, Henttonen H, Mäkelä S, et al. Uncovering the mysteries of hantavirus infections. Nat Rev. 2013;11:539-50.

17. Rosado FG, Kim AS. Hemophagocytic lymphohistiocytosis: an update on diagnosis and pathogenesis. Am J Clin Pathol. 2013;139:713-27.

18. Henter Jl, Horne A, Arico M, et al. HLH-2004: diagnostic and therapeutic guidelines for hemophagocytic lymphohistiocytosis. Pediatr Blood Cancer. 2007:48:124-31.

19. Marsh RA. Epstein-Barr virus and Hemophagocytic Lymphohistiocytosis. Front Immunol. 2017:8:1902.

\section{Publisher's Note}

Springer Nature remains neutral with regard to jurisdictional claims in published maps and institutional affiliations.
Ready to submit your research? Choose BMC and benefit from:

- fast, convenient online submission

- thorough peer review by experienced researchers in your field

- rapid publication on acceptance

- support for research data, including large and complex data types

- gold Open Access which fosters wider collaboration and increased citations

- maximum visibility for your research: over $100 \mathrm{M}$ website views per year

At BMC, research is always in progress.

Learn more biomedcentral.com/submissions 